\title{
Induction of callus and adventitious shoots on epicotyl and hypocotyl segments of cumaru (Dipteryx odorata)
}

Paulo Tarso Barbosa Sampaio', Lyana Silva Jardim², Ariel Dotto Blind ${ }^{2 *}$, Flavio Mauro Souza Bruno'

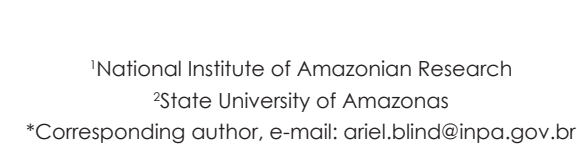

*Corresponding author, e-mail: ariel.blind@inpa.gov.br

\begin{abstract}
Somatic embryogenesis from callus induced in epicotyl and hypocotyl segments can be viable native species in order to better -benefit ratio costs, and rates of clonal multiplication. In this sense, two trials were established to induce callus and adventitious buds on hypocotyl and epicotyl segments of cumaru bean seedlings germinated in vitro in different concentrations and combinations of growth regulators. At first, we used the MS medium supplementwith ANA (0.0, $\left.1.5 \mathrm{mg} . \mathrm{L}^{-1}\right)$ and TDZ $\left(0.0,4.0\right.$ and $8.0 \mathrm{mg}^{. \mathrm{L}^{-1}}$ ) distributed in factorial $2 \times 3 \times 2$ (x auxin cytokinin $x$ explant) with eight replications. In the second, it was used the WPM medium supplemented with BAP (2.0 $\left.\mathrm{mg} \mathrm{L}^{-1}\right)$ and plus 2,4-D (2.0 and $\left.4.0 \mathrm{mg} \mathrm{L}^{-1}\right)$ in a factorial $2 \times 2$ (auxin $x$ explant) with 15 repetitions each. They were evaluating callus formation and the average number of adventitious shoots during the period of 90 days. The results indicated that the highest average for callus formation was observed when the explants were subjected to concentrations of 8.0 $\mathrm{mg} \mathrm{L}^{-1} \mathrm{TDZ}$ combined with $1.5 \mathrm{mg} \mathrm{L}^{-1}$ ANA in MS medium. For the formation of buds, the WPM medium plus $2.0 \mathrm{mg} \mathrm{L}^{-1} 2,4-\mathrm{D}$ in the second experiment, induced higher number of shoots, being significant the use of auxin, and its interaction with the type of explant.
\end{abstract}

Keywords: calogêns, Cumarú, Dipteryx odorata (Aubl.) Willd

\section{Introduction}

The cumaru (Dipteryx odorata (Aubl.) Willd.) is a species of higheconomic value, together with the construction industry, pharmaceuticals, food products and biocosmetics. The cumaru oil extracted from the seeds is used for the aromatization of chocolates, beverages, tobaccos, perfumes and the manufacture of soaps (Sampaio, 2000; Uchida \& Campos, 2000; Araújo et al., 2004).

Considering the growing demand for products derived from forest plantations (Butler \& Laurance 2008; Das, 2011; Lavanya et al., 2014), the development of new techniques for highproductivity seedling production is one of the objectives of the genetic breeding programs for the species (Sampaio, 2000; Pinto et al., 2008). In this scenario, the in vitro micropropagation of forest species appears as a viable technique as pointed out by Reed et al. (2011), being organogenesis and somatic embryogenesis among the most promising techniques for this objective (Guerra et al., 1999; Lavanya et al., 2014). There are a few information on the in vitro propagation methods of cumaru, among other forest species (Das, 2011; Penã-Ramirez et al., 2011), indicating the need to deepen existing studies, such as callus induction, for multiplication by embryogenic route, morphogenic or even cryopreservation of species that occur in the 
Amazon biome (Steinmacher et al., 2007).

Somatic embryogenesis is a regenerative process of plants in which bipolar structures, similar to zygotic embryos, are formed by somatic cells with no vascular connection to the tissues of the initial explant (Zimmerman, 1993; Jiang et al., 2012), making an asexual propagation system, especially for woody and palmaceous species considered difficult to regenerate by conventional asexual propagation methods (Kielse et al., 2007; Moura et al., 2008).

For a maximized proliferation of regenerative calluses and adventitious shoots, it is necessary to consider besides the composition of the culture medium as point out by Tokuji \& Kuriyama (2003) and Shen et al. (2008), the type of explant to be used (Jiang et al., 2012), conditions of the growing environment (Tokuji \& Kuriyama, 2003), and the use of growth regulators (Jiménes, 2005; Lavanya et al., 2014) because these latter act significantly in the mitotic recovery of differentiated tissues, modifying the quiescent cellular metabolism in an active metabolism, being able to provide a large number of individuals (Quiroz-Figueroa, 2006; Hendrawati et al., 2012). In this context, the objective of this work was to evaluate the explants types and the concentrations of growth regulators able to promote the formation of regenerative calluses and adventitious shoots in segments of epicotyl and hypocotyl of Dipteryx odorata, aiming the propagation and multiplication of the species.

\section{Material and methods}

The experiments were carried out in the Plant Tissue Culture Laboratory of the State University of Amazonas (UEA).

\section{Explants preparation}

Mature cumaru seeds (Figure 1A) were immersed in folicur solution $\left(5.0 \mathrm{~mL} . \mathrm{L}^{-1}\right)$ over 24 hours, washed in autoclaved water and taken to a laminar flow chamber, where they remained in commercial sodium hypochlorite solution at $10 \%$ (with $2.5 \%$ active chlorine) for 20 minutes, and rinsed abundantly with autoclaved water. Then the embryos were excised and inoculated (Figure 1B) in MS medium (Murashige \& Skoog, 1962), added with $25 \mathrm{gL}^{-1}$ sucrose, $3.8 \mathrm{gL}^{-1}$ agar,
$30 \mathrm{mg} \cdot \mathrm{L}^{-1}$ ascorbic acid, $15 \mathrm{mg} \cdot \mathrm{L}^{-1}$ of $\mathrm{GA}_{3}$ and $20 \mathrm{mg} . \mathrm{L}^{-1}$ of PVP. After inoculation, the embryos were maintained in a chamber BOD-type, kept in the dark at a temperature of $27^{\circ} \mathrm{C}$ for 48 hours, and then carried to the growth room where they remained for 30 days under controlled environmental conditions: temperature of $27^{\circ} \mathrm{C} \pm$ $2{ }^{\circ} \mathrm{C}$, photoperiod of 16 hours; relative humidity of $70 \%$ and luminosity of $52 \mu \mathrm{mol} . \mathrm{m}^{-2} \cdot \mathrm{s}^{-1}$ of irradiance.

Induction of callus and adventitious shoots

Two distinct experiments were carried out to induce calluses and sprouts. The epicotyl (Figure 1D) and hypocotyl (Figure 1E) segments obtained from in vitro germinated seedlings (Figure 1C) that were segmented and inoculated in MS medium (Experiment I), and WPM medium supplemented with $2.0 \mathrm{mg} \cdot \mathrm{L}^{-1}$ of BAP (Experiment II), and both media added with $30 \mathrm{gL}^{-1}$ of sucrose, $4.0 \mathrm{gL}^{-1}$ of agar, with different doses and combinations of growth regulators. In the first experiment, ANA (0.0, $\left.1.5 \mathrm{mg} \cdot \mathrm{L}^{-1}\right)$ and TDZ (0.0, 4.0 and $8.0 \mathrm{mg}^{\left.-\mathrm{L}^{-1}\right)}$ were used, and in the second, 2,4- D (2.0 and $\left.4.0 \mathrm{mg}^{-\mathrm{L}^{-1}}\right)$, the two of them with respective combinations.

The experimental design was a randomized complete block design, with factorial 2X3X2 (auxin $x$ cytokinin $x$ explant type), with 8 blocks and 2 replicates each. In the second, the completely randomized, 2x2 factorial (auxin $x$ explant type) was used, with 15 replicates each. The data were submitted to ANOVA and the comparison of means of treatments was done by the Tukey test at the $5 \%$ probability level.

\section{Results and discussion}

After 90 days of incubation, callus formation was not observed in control treatments lacking growth regulators. This demonstrates a certain dependence on the exogenous source of phytoregulators for activation, dedifferentiation and cell division in the explants as evidenced in Figure 1. Most of the callus was friable, translucent light yellow to light brown, with small greenish spots, resembling the formation of somatic embryos (Figure 1G).

According to ANOVA, both experiments provided a significant effect at $1 \%$ probability for TDZ (Table 1) and 2,4-D doses (Table 2). However, 
in the experiment $\mathrm{l}$, there was also a significant effect for the explant type, with emphasis on the epicotyl; and in experiment II, there was interaction between the factors.

Table 1. General means for callus and shoot formation in Dipteryx odorata, as a function of the different thidiazuron (TDZ) doses and the explant type used in experiment I.

\begin{tabular}{lcc}
\hline TDZ doses & Callus mean & ${ }^{*}$ \\
\hline $0.0 \mathrm{mg} \cdot \mathrm{L}^{-1}$ & $0.31 \mathrm{~b}$ & $0.31 \mathrm{~b}$ \\
$4.0 \mathrm{mg} \cdot \mathrm{L}^{-1}$ & $2.22 \mathrm{a}$ & $3.18 \mathrm{a}$ \\
$8.0 \mathrm{mg} \cdot \mathrm{L}^{-1}$ & $3.19 \mathrm{a}$ & $2.75 \mathrm{a}$ \\
\hline Explant Type & & \\
\hline Hypocotyl & $1.45 \mathrm{~b}$ & $2.14 \mathrm{a}$ \\
Epicotyl & $2.35 \mathrm{a}$ & $2.02 \mathrm{a}$ \\
\hline Means followed by the same letter do not differ significantly from each other at $1 \%$ of probability by Tukey test.
\end{tabular}

Table 2. General means for callus and shoot formation in Dipteryx odorata, as a function of the 2,4-D doses and their interaction with the explant type used in experiment II.

\begin{tabular}{|c|c|c|}
\hline 2,4-D doses & Callus mean* & Shoots mean** \\
\hline $2.0 \mathrm{mg} \cdot \mathrm{L}^{-1}$ & $2.27 \mathrm{a}$ & $4.73 a$ \\
\hline $4.0 \mathrm{mg} \cdot \mathrm{L}^{-1}$ & $1.70 \mathrm{~b}$ & $2.13 b$ \\
\hline Explant x 2,4-D & Callus mean* & Shoots mean** \\
\hline Epicotyl X 2.0 mg.. $\mathrm{L}^{-1}$ & $1.80 \mathrm{Ba}$ & $1.70 a$ \\
\hline Epicotyl X 4.0 mg. $\mathrm{L}^{-1}$ & $1.73 \mathrm{Aa}$ & $1.40 \mathrm{a}$ \\
\hline Hypocotyl X 2.0 mg. $\mathrm{L}^{-1}$ & $2.73 \mathrm{Aa}$ & $1.70 \mathrm{a}$ \\
\hline Hypocotyl X 4.0 mg.L-1 & $1.67 \mathrm{Ab}$ & $1.50 \mathrm{a}$ \\
\hline
\end{tabular}

The treatments E3, H5 and E5 (Figure 1F) were the ones that showed the highest mean for callus formation, and when TDZ doses in isolation were increased in the treatments (experiment I), resulted in increase of the mean number of callus formed by explant (Table 3).
With respect to the induction of adventitious shoots, it was observed that they were formed from the green spots originated from the callus formation (Figure 1H). Although the acetic carmin test was not performed for the verification of viable embryos in these

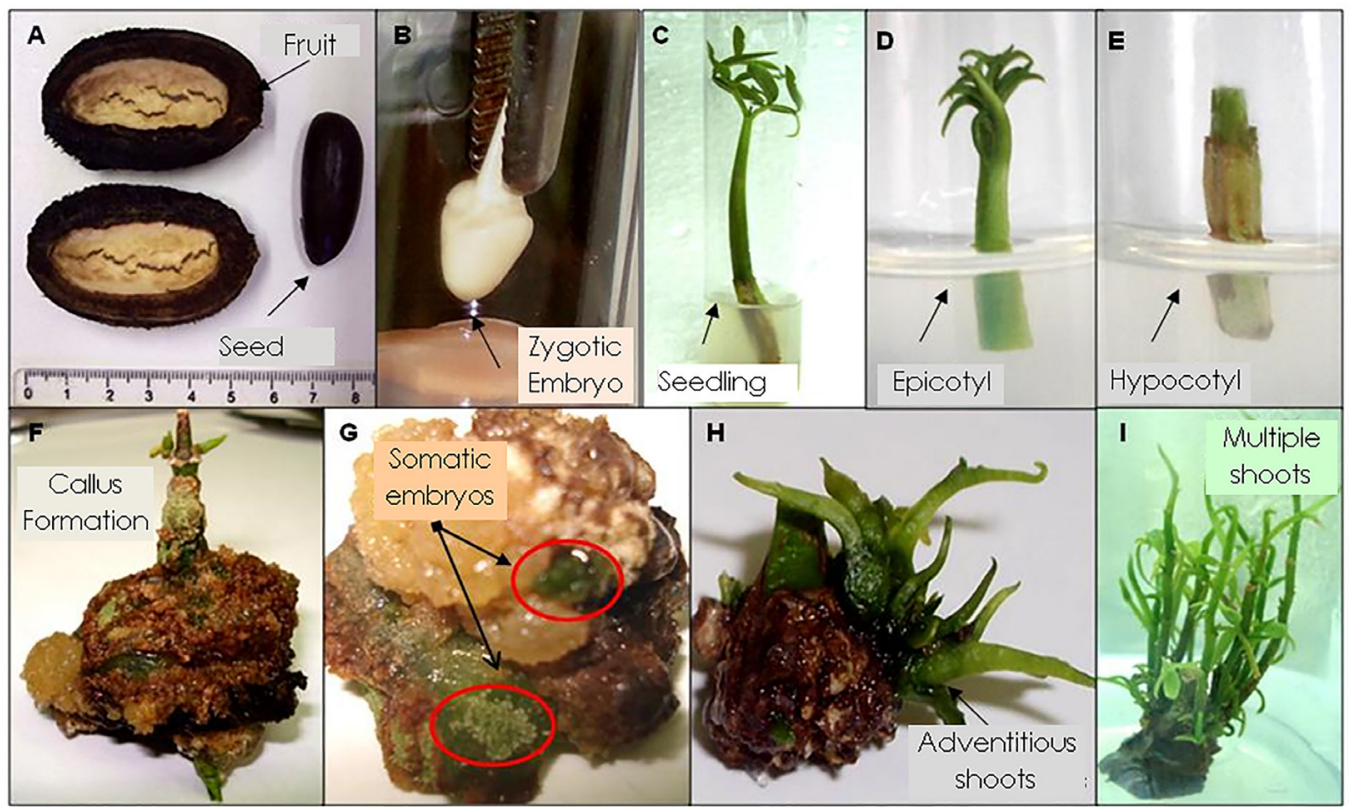

Figure 1: Dipteryx odorata (Aubl) Willd. Fruit and seed (A); Inoculation of the zygotic embryo in MS medium (B); In vitro germinated seedling after 15 days (C); Segments of epicotyl and hypocotyl, respectively, used in the experiments (D and E); Induced epicotyl segment callus formation in MS medium containing ANA (1.5 mg. $\left.\mathrm{L}^{-1}\right)$ and TDZ (4.0 $\left.\mathrm{mg}^{-\mathrm{L}^{-1}}\right)$ (F); Formation of somatic embryos (hypothesis), originating from friable callus (G); Hypocotyl segment-induced adventitious shoots induced in WPM medium containing $2.0 \mathrm{mg} \cdot \mathrm{L}^{-1}$ of BAP $+2.0 \mathrm{mg}^{-\mathrm{L}^{-1}}$ of 2,4-D $(\mathrm{H})$; Elongation of multiple shoots in hypocotyl segment after 120 days (I). 
callus structures, it was observed that the results obtained were given by the explants, which are proven capable of originating an indirect response, either organogenic or embryogenic, where initially there was a differentiation (callus) and the arising of friable regions capable of causing sprouts in most treatments.

In order to induce shoots, treatments $\mathrm{H} 2$ (Table 3), E6 and H6 (Table 4) were the ones that presented the highest means according to the Tukey test, revealing a significant effect for TDZ and 2,4-D (Tables 1 and 2, respectively), the type of explant used was not relevant.

Despite the advances observed in the study of somatic embryogenesis as reported by Reed et al. (2011) and Lavanya et al. (2014), it is still limited the understanding of the stimuli and conditions necessary for induction and control of this process. Although embryogenic cultures are generally initiated from embryonic, juvenile or mature explants (Guerra et al., 1999), and grown in semi-solid medium containing auxins combined or not with cytokinins (Steinmacher et al., 2007; Das, 2011), the answer may not be isolated (Hendrawati et al., 2012), but rather the physiological stimulus that the explant can manifest by such manipulations to the one that precedes the incubation.

Table 3. Means of the treatments obtained by explant in the formation of callus and shoots in Dipteryx odorata, due to the combination of growth regulators ANA and TDZ, and the type of explant used in experiment I.

\begin{tabular}{|c|c|c|c|c|}
\hline \multirow[t]{2}{*}{ Treat. } & \multicolumn{2}{|c|}{ ANA and TDZ Doses } & \multirow[t]{2}{*}{ callus mean/explant } & \multirow[t]{2}{*}{ Shoot mean/explant } \\
\hline & ANA (mg. $\left.\mathrm{L}^{-1}\right)$ & TDZ (mg. $\left.\mathrm{L}^{-1}\right)$ & & \\
\hline$E_{0}$ & 0.0 & 0.0 & 0.0 & 0.50 \\
\hline$E_{1}$ & 1.5 & 0.0 & 0.75 & 0.75 \\
\hline$E_{2}$ & 0.0 & 4.0 & 1.75 & 2.37 \\
\hline$E_{3}$ & 1.5 & 4.0 & 3.87 & 2.37 \\
\hline$E_{4}$ & 0.0 & 8.0 & 2.0 & 2.37 \\
\hline \multirow[t]{2}{*}{$E_{5}^{4}$} & 1.5 & 8.0 & 3.62 & 2.25 \\
\hline & ANA (mg. $\left.\mathrm{L}^{-1}\right)$ & TDZ (mg. L $\left.^{-1}\right)$ & & \\
\hline $\mathrm{H}_{0}$ & 0.0 & 0.0 & 0.0 & 0.0 \\
\hline $\mathrm{H}_{1}$ & 1.5 & 0.0 & 0.50 & 0.0 \\
\hline $\mathrm{H}_{2}$ & 0.0 & 4.0 & 1.75 & 4.87 \\
\hline $\mathrm{H}_{3}$ & 1.5 & 4.0 & 1.50 & 3.12 \\
\hline $\mathrm{H}_{4}$ & 0.0 & 8.0 & 3.25 & 2.75 \\
\hline $\mathrm{H}_{5}^{4}$ & 1.5 & 8.0 & 3.87 & 3.62 \\
\hline
\end{tabular}

Table 4. Means of the treatments obtained by explant in the formation of callus and shoots in Dipteryx odorata, due to the combination of 2,4-D doses and explant type used in experiment II.

\begin{tabular}{cccc}
\hline Treat. & $2,4-D$ doses & callus mean/explant & Shoots mean /explant \\
\hline $\boldsymbol{E}_{6}$ & $2.0 \mathrm{mg} \cdot \mathrm{L}^{-1}$ & 1.80 & 4.33 \\
$\boldsymbol{E}_{7}$ & $4.0 \mathrm{mg} \cdot \mathrm{L}^{-1}$ & 1.73 & 1.67 \\
$\boldsymbol{H}_{6}$ & $2.0 \mathrm{mg} \cdot \mathrm{L}^{-1}$ & 2.73 & 5.13 \\
$\boldsymbol{H}_{7}$ & $4.0 \mathrm{mg} \cdot \mathrm{L}^{-1}$ & 1.67 & 2.60 \\
\hline
\end{tabular}

Studies realized by Shen et al. (2008), with cultivars of Dieffenbanchia for example, verified that the effect on the type of explant used in the indirect formation of shoots would be the difference of the existence of competent organogenic or embryogenic cells, together with the type and the concentration of growth regulators. Similarly, Steinmacher et al. (2007) verified that the choice of meristematic cells is determinant to the cell conservation and differentiation in Bactris gasipaes.
The use of these data as a strategy to optimize future protocols, whose results include rooting and acclimatization tests of acquired shoots, making plant tissue culture an effective propagation method for Dipteryx odorata are in prospect.

\section{Conclusions}

The best means for callus formation in Dipteryx odorata were obtained in treatments containing 8.0 mg. $\mathrm{L}^{-1}$ of TDZ in MS medium; 
The use of $2.0 \mathrm{mg}^{-L^{-1}}$ of BAP and 2,4-D in WPM medium induced the higher mean number of multiple adventitious shoots in the species for the epicotyl and hypocotyl explants.

\section{Acknowledgment}

The authors thank to the Foundation for Research Support of the State of Amazonas, and the National Council for Scientific and Technological Development, for granting financial support.

\section{References}

Araújo, V.F., Echeverria, R.M., Pastore, F.J. 2004. Produção não-madeireira e desenvolvimento sustentável na Amazônia. 12p. http://itto.int/files/ itto_project_db_input/2202/Technical/3 <Acesso em 14 de Jan. 2012>.

Butler, R.A., Laurance, W.F. 2008. New strategies for conserving tropical forests. Trends in Ecology \& Evolution 23: 469-472.

Das, P. 2011. "In vitro somatic embryogenesis in some oil yielding tropical tree species". American Journal of Plant Sciences 2: 217-222.

Guerra, M.P., Torres, A.C., Teixeira, J.B. 1999. Embriogênese somática e sementes sintéticas. In: Torres, A.C.; Caldas, L.S.; Buso, J.A. (ed.) Cultura de tecidos e transformação genética de plantas. ABCT/EMBRAPA-CNPH, Brasília, Brasil. p. $533-568$.

Hendrawati, O., Hille J., Woerdenbag, H. J. Quax, W. J., Kayser, O. 2012. In vitro regeneration of wild chervil (Anthriscus sylvestris L.). In Vitro Cellular \& Developmental Biology - Plant 48: 355 - 361.

Jiang, W., Chen L., Pan, Q., Qiu, Y., Shen, Y., Fu, C. 2012. An efficient regeneration system via direct and indirect organogenesis for the medicinal plant Dysosma versipellis (Hance) M. Cheng and its potential as a podophyllotoxin source. Acta Physiologiae Plantarum 34: 631-639.

Jiménez, V. M. 2005. Involvement of plant hormones and plant growth regulators on in vitro somatic embryogenesis. Plant Growth Regulation 47: 91-110

Kielse, P.V.N., Franco, E.T.H., Frassetto, E.G. 2007. Indução de calogênese em explantes de Parapiptadenia rígida. Revista Brasileira de Biociencias 5: $84-86$.

Lavanya, A. R., Muthukrishnan, S., MuthuKumar, J. H. M., Franklin B., Senthil Kumar, T., Kumaresan, V., Rao, M. V. 2014. Indirect organogenesis from various explants of Hildegardia populifolia (Roxb.) Schott \& Endl. - A threatened tree species from
Eastern Ghats of Tamil Nadu, India. Journal of Genetic Engineering and Biotechnology 12: 95101.

Moura, E.F., Ventrella, M.C., Motoike, S.Y., Sá, A.Q.J., Carvalho, M., Manfio, C.E. 2008. Histological study of somatic embriogenesis induction on zygotic embryos of macaw palm (Acrocomia aculeata (Jaca.) Lodd. Ex Martius). Plant Cell Tissue and Organ Culture 95:175 - 184.

Murashige, T., Skoog, F.A. 1962. A revised medium for a rapid growth and bioassays with tobacco tissues cultures. Plant Physiology 15: 473 - 479.

Peña-Ramirez, Y. J., Garcia-Shesenã, I., Hernández-Espinoza, A., DomínguezFernández, A., Barredo-Pool, F.A., GonzálezRodríguez, J.A., Robert, M. L. 2011 . Induction of somatic embryogenesis and plant regeneration in the tropical timber tree Spanish red cedar [Cedrela odorata L. (Meliaceae)]. Plant Cell, Tissue and Organ Culture 105: 203-209.

Pinto, A. M., Morellato, L.P.C., Barbosa, A. P. 2008. Fenologia reprodutiva de Dipteryx odorata (Aubl.) Willd (Fabaceae) em duas áreas de floresta na Amazônia Central. Acta Amazonica, $38(4): 643-650$.

Quiroz-Figueroa, F.R., Rojas-Herrer A,R., GalazAvalos, R.M., Loyola-Vargas,V.M. 2006. Embryo production through somatic embryogenesis can be used to study cell differentiation in plants. Plant Cell, Tissue and Organ Culture 86: 285-301.

Reed, B.M., Sarasan, V., Kane, M., Burn, E., Pence, V.C. 2011. Biodiversity conservation and conservation biotechnology tools. In Vitro Cellular \& Developmental Biology - Plant. 47: 1-4.

Sampaio, P.T.B. 2000. Cumaru (Diperyx odorata). In: Clay, J.W.; Sampaio, P.T.B.; Clement, C.R. (ed.) Biodiversidade Amazônica: exemplos e estratégias de utilização. 1.ed. Manaus: Programa de desenvolvimento empresarial e tecnológico. INPA/SEBRAE-AM, Manaus, brasil. p. 280-289.

Shen, X., Kane, M.E., Chen, J. 2008. Effects of genotype, explant source and plant growth regulators on indirect shoot organogenesis in Dieffenbachia culticars. In Vitro Celular and Development Biology - Plant 44: 282 - 288.

Steinmacher, D.A., Saldanha, C.W., Clement, C.R., Guerra, M.P. 2007. Cryopreservation of peach palm zygotic embryos. Cryoletters 28: 1322

Tokuji, Y., Kuriyama, K. 2003. Involvement of gibberellins and cytokinin in the formation of embryogenic cell clumps incarrot (Daucuscarota). Journal Plant Physiology 160: 133-141. 
Uchida, T., Campos, M. A. A. 2000. Influência do sombreamento no crescimento de mudas de cumaru (Diperyx odorata (Aubl.) Willd. - Fabaceae), cultivadas em viveiro. Acta Amazonica 30 (1): 107 - 114.

Zimmerman, J,L, 1993. Somatic embryogenesis: a model for early development in highter plants. Plant C ell Tissue and Organ Culture 5: 1411 1423. 